\title{
Erythrogram, leukogram, and acute phase protein reference intervals for healthy newborn Murrah buffalo calves (Bubalus bubalis) within the first month of life
}

\author{
André Marcos Santana ${ }^{1}$ Daniela Gomes da Silva ${ }^{1}$ - Virna Clemente ${ }^{1}$. \\ Priscila Arrigucci Bernardes ${ }^{1}$. Lucas José Luduverio Pizauro ${ }^{1}$. \\ Clarissa Helena Santana ${ }^{1} \cdot$ Funmilola Clara Thomas $^{2} \cdot$ Eilidh McCulloch $^{3}$ • \\ Peter David Eckersall $^{3}$ • José Jurandir Fagliari ${ }^{1}$
}

Received: 6 July 2016 / Accepted: 28 February 2017 / Published online: 11 March 2017

(C) Springer-Verlag London 2017

\begin{abstract}
Establishing of reference intervals (RI) for hematologic variables and blood serum acute phase proteins (APP) of healthy newborn buffaloes is an important tool for monitoring alterations during infection and inflammation. Considering the scarcity of published data on newborns, the aim of the study was to establish RI for hematologic variables and APP from healthy newborn buffaloes. Blood samples from 28 healthy Murrah buffalo calves, 10-30 days old, were selected to determine RI. Fourteen hematologic and four blood APP variables were analyzed. Before collection of blood samples, calves were subjected to physical examination (rectal temperature, degree of dehydration, and fecal consistency) and only calves that were considered healthy were included in the study. The Anderson-Darling test was used to assess normal distribution of values. The Dixon test and Tukey test were used to identify outliers. RI and 90\% CI were determined using standard/robust methods and Box-Cox transformation. RI for variables analyzed were the following: (1) hematologic variables: RBC 7.5-12.9 × 10\% $/ \mu \mathrm{L}, \mathrm{HGB} 10.6-19.0 \mathrm{~g} / \mathrm{dL}$, packed cell volume $33.1-54.8 \%$, mean corpuscular volume
\end{abstract}

André Marcos Santana

andrevetms@gmail.com

1 Department of Veterinary Clinic and Surgery, FCAV, UNESP, Via de Acesso Prof. Paulo Donato Castellane s/n,

Jaboticabal, SP 14884-900, Brazil

2 Department of Veterinary Physiology and Pharmacology, College of Veterinary Medicine, Federal University of Agriculture, Abeokuta, Nigeria

3 Institute of Biodiversity, Animal Health and Comparative Medicine, College of Medical, Veterinary and Life Sciences, University of Glasgow, Glasgow, UK
36.2-50.6 fL, mean corpuscular hemoglobin 12.1-17.3 pg, mean corpuscular hemoglobin concentration 28.1-42.9 g/ $\mathrm{dL}$, platelets $361-1081 \times 10^{3} / \mu \mathrm{L}, \mathrm{WBC} 6.56-18.2 \times 10^{3} /$ $\mu \mathrm{L}$, lymphocytes $4.15-12.8 \times 10^{3} / \mu \mathrm{L}$, segmented neutrophils $0.950-10.6 \times 10^{3} / \mu \mathrm{L}$, band neutrophils $0-0.160 \times 10^{3} / \mu \mathrm{L}$, monocytes $0-0.754 \times 10^{3} / \mu \mathrm{L}$, eosinophils $0-0.326 \times 10^{3} /$ $\mu \mathrm{L}$, and basophils $0-0.149 \times 10^{3} / \mu \mathrm{L}$ and (2) APP variables: fibrinogen 2.49-9.50 g/L, haptoglobin 0.02-0.56 g/L, serum amyloid A (SAA) $3.70-97.51 \mu \mathrm{g} / \mathrm{mL}$, and C-reactive protein (CRP) $0.02-2.78 \mu \mathrm{g} / \mathrm{mL}$. In conclusion, hematologic and acute phase protein RI have been documented and can be used as a physiologic database to help the interpretation of laboratory results of newborn buffaloes during infection and inflammation conditions.

Keywords Haptoglobin · Hematology · Infection · Inflammation $\cdot$ Neonatal

\section{Introduction}

The first month of life is a critical period for newborn buffaloes where two of the major causes of morbidity and mortality are diarrhea and pneumonia (Khan et al. 2009; Anwarullah et al. 2014; Naag et al. 2015). In particular, diarrhea, involving a complex etiology comprising infectious and parasitic pathogens (Anwarullah et al. 2014; Silva et al. 2015), can be responsible for until $23.7 \%$ of deaths that occur in neonatal (Sunil Chandra and Mahalingam 1994).

To address diseases in newborns, the clinical evaluation of neonates requires, besides the physical examination, the use of complementary laboratory tests such as measurement of blood serum components, which can enable the detection of anemia, 
inflammation, and infection conditions. For example, modifications of blood serum components in diarrheic newborn bovines infected with Salmonella dublin (Silva et al. 2010, 2011) and newborn buffaloes infected with Salmonella thyphimurium (Clemente et al. 2016) have been studied. Important alterations have been linked to inflammation and infection, such as increases in acute phase proteins (APP) fibrinogen, ceruloplasmin and haptoglobin, and leukocytosis. Studies with bovine calves during outbreak of respiratory disease caused by bovine respiratory syncytial virus have shown changes in haptoglobin, serum amyloid A (SAA), and LBP (Orro et al. 2011).

In buffaloes, studies with alterations in the hemogram and APP in newborn diseased animals are scarce (Clemente et al. 2016; Kabu and Sayin 2016). In adult buffaloes, studies have shown important alterations in blood serum components in animals with traumatic reticuloperitonitis and pericarditis (Saleh et al. 2008; El-Ashker et al. 2013; Neamat-Allah 2015), abomasal ulcer (Tajik et al. 2012), animals experimentally infected with Pasteurella multocida (Horadagoda et al. 2001, 2002), with uterine torsion (Ali et al. 2011), and in animals with fever, parasitic infestations, and respiratory disorders (Singh et al. 2013).

However, to use results of complementary laboratory tests to assess disease, the study of reference intervals (RI) for each of the tests used will help to establish a physiologic database and can help to minimize errors in clinical decision-making. The use of inappropriate RI can lead to both over- and underdiagnoses of disease, which can compromise the wellbeing of the animal and increase healthcare costs for the owner (Sample et al. 2015).

In healthy adult buffaloes, studies on the hemogram and APP have been performed in lactating and non-lactating buffaloes (Ciaramella et al. 2005; Gomes et al. 2010; França et al. 2011a; El-Ashker et al. 2013; Ellah et al. 2013b; Kumar et al. 2014), in pregnant and post-calving buffaloes (Fagliari et al. 1998a; Ellah et al. 2013a, c), and in buffalo heifers (Ellah et al. 2014).

In healthy newborns until 30 days of life, studies with erythrogram (Brun-Hansen et al. 2006; Benesi et al. 2012a), leukogram (Benesi et al. 2012b), and APP (Fagliari et al. 1998b, 2006; Rizzoli et al. 2006; Nikunen et al. 2007; Orro et al. 2008, 2011; Tóthová et al. 2015) have been widely assessed in bovines but very rarely in buffaloes (Fagliari et al. 1998b; Clemente et al. 2016), where studies with healthy calves have been performed in groups of animals ranging from 0 to 3 months and 0 to 6 months of life (Gomes et al. 2010; França et al. 2011a). Therefore, studies of the RI in newborn buffaloes with the age range between 0 and 30 days of life, a period in which the incidence of diseases is high, would be of great benefit in readily identifying health compromising conditions, especially as alterations in blood composition occur after the first month of life. Also, when comparing studies performed in calves and adult animals, it is clear that the use of blood serum components of adult animals for analyzing calves is not accurate, since many alterations are known to occur with advancing age (Costa et al. 2000; Ciaramella et al. 2005; Gomes et al. 2010; França et al. 2011a).

Considering the lack of published works associated to newborn buffalo calves, the aim of the study was to establish RI for hematologic variables and APP from healthy newborn buffaloes in the first month of life, in order to help monitoring alterations during infection, inflammation, and trauma.

\section{Materials and methods}

\section{Ethical standards}

This research was approved by the Ethics Committee on Animal Use of Faculdade de Ciências Agrárias e Veterinárias, FCAV/UNESP (protocol number: 010885-08).

\section{Animals and study area}

Twenty-eight healthy Murrah buffalo calves, 10-30 days of life, from commercial herds localized in São Paulo state, Brazil, constituted the experimental group. Calves were kept together with the lactating buffaloes, which were kept in a semi-intensive system with diet based on roughage. Calves were fed with fresh buffalo milk and also had access to commercial feed, hay, and water ad libitum. All calves that participated in the experiment ingested colostrum.

\section{Physical examination}

Inclusion criteria Before collection of blood samples, all calves were subjected to physical examination. Feces were analyzed to check for signs of diarrhea, blood, and mucus. Rectal temperature was also measured to check for signs of hyperthermia. Degree of dehydration was also measured. A total of 28 newborn buffaloes that were normal following physical examination were included in the study. For these calves, rectal temperature ranged between 34.7 and $39.2{ }^{\circ} \mathrm{C}$, indicating the absence of hyperthermia.

\section{Blood sample collection and preparation}

Blood sampling was performed by puncture of the jugular vein using a vacuum collection system $(25 \times 8 \mathrm{~mm}$ needles $)$, after local antisepsis with iodized alcohol.

Blood samples were collected into siliconized plastic tubes containing EDTA (BD Vacutainer, $4.0 \mathrm{~mL}$ ), to perform hemogram analyses and to analyze concentrations of the APP fibrinogen. To determine the fibrinogen concentration, 
samples with EDTA were centrifuged at $1000 \times g$ for $5 \mathrm{~min}$, to obtain the plasma to accomplish the analysis.

Blood samples were also collected into siliconized plastic tubes without anticoagulant (BD Vacutainer, $10 \mathrm{~mL}$ ) prior to analysis of the APP using ABX Pentra 400 analyzer (haptoglobin) and ELISA methods (SAA, C-reactive protein (CRP)). These samples were centrifuged at $1000 \times g$ for $10 \mathrm{~min}$ after clot retraction, and 1.5-mL aliquots of serum were stored in Eppendorf tubes and frozen $\left(-20^{\circ} \mathrm{C}\right)$ until analysis was performed.

\section{Laboratory analysis}

Hemogram including RBC count, HGB concentration, packed cell volume (PCV), mean corpuscular volume $(\mathrm{MCV})$, mean corpuscular hemoglobin $(\mathrm{MCH})$, mean corpuscular hemoglobin concentration (MCHC), PLT and total WBC count was performed using automated hematology pocH-100iV Diff analyzer (Sysmex Corporation, Kobe, Japan). Differential WBC count was performed on blood smear stained with modified Rosenfeld dye by optical microscopy (Garcia-Navarro 1994). Plasma concentrations of fibrinogen were measured by heat precipitation method (Millar et al. 1971).

An ABX Pentra 400 (Horiba ABX SAS, Montpellier, France) was used to analyze serum concentrations of haptoglobin with the methods described in Eckersall et al. (1999) (Table 1). ELISA methods were used to analyze serum concentrations of SAA (Tridelta Development Limited, Maynooth, Co. Kildare, Ireland) and CRP (Life Diagnostics, Inc., West Chester, Pennsylvania, USA) (Table 1).

\section{Statistical analysis}

RI were determined according to the guidelines of the American Society for Veterinary Clinical Pathology (ASVCP) (sample size: $20 \leq \times<40$ ) (Friedrichs et al. 2012). The Anderson-Darling test was used to assess normal distribution of values with a $p<0.05$ (Reference Value Advisor) (Geffré et al. 2011). The Dixon test and Tukey test (3xIQR, 1.5xIQR) were used to identify outliers and suspect outliers
(Reference Value Advisor) (Geffré et al. 2011). RI and 90\% CI for lower and upper limits were determined using untransformed data, when data distribution was Gaussian (standard) or symmetric but not Gaussian (robust). When data was not symmetric by using untransformed standard and robust methods, the Box-Cox transformation was performed so to normalize data (Reference Value Advisor).

\section{Results and discussion}

All variables were analyzed using 28 samples except haptoglobin, SAA, and CRP. For haptoglobin, SAA, and CRP, 20 samples were used. However, considering that the study included 20 or more samples for each variable, RI were able to be calculated using the Reference Value Advisor (Geffré et al. 2011) according to the guidelines of the ASVCP for sample size between 20 and 40 (Friedrichs et al. 2012). Therefore, RI for 14 hematologic variables and 4 blood serum APP variables were calculated and are arranged in Tables 2 and 3, respectively.

The hemogram is a simple and cheap method to assess blood alterations associated to pathological conditions, such as anemia, dehydration, inflammation, and infection, and can be a valuable complementary data for diagnosis, prognosis, and evaluation of infectious diseases. In buffaloes, studies with the hemogram have been focused on adult animals, greater than 1 year old and under different conditions, such us lactating buffaloes (Ellah et al. 2013b), non-lactating buffaloes (Ciaramella et al. 2005), pregnant and post-calving buffaloes (Fagliari et al. 1998a; Ellah et al. 2013a, c), and buffalo heifers (Ellah et al. 2014). However, it is clear that the use of blood serum constituents of adult animals for analyzing calves is not accurate, since many alterations occur with advancing age (Costa et al. 2000; Gomes et al. 2010; França et al. 2011a).

Gomes et al. (2010), comparing the erythrogram between 0-3-month-old and 1-5-year-old buffaloes and França et al. (2011a), comparing the erythrogram between 0-6 month-old and 1-2-year-old buffaloes, obtained statistically different results among groups, observing a decrease in PCV, RBC, and HGB with advancing age. This
Table 1 Analytic methods for APP variables measured in newborn buffalo calves (Bubalus bubalis)

\begin{tabular}{lll}
\hline Variables & Method & Absorbance required (nm) \\
\hline Fibrinogen & Heat precipitation and refractometer reading & - \\
Haptoglobin & Hemoglobin binding $^{\mathrm{b}}$ & 600 \\
SAA & ELISA $^{\mathrm{c}}$ & 450 \\
CRP & ELISA $^{\mathrm{d}}$ & 450 \\
\hline & & \\
${ }^{\mathrm{a}}$ ATAGO & \\
${ }^{\mathrm{b}}$ Based on the method of Eckersall et al. (1999) on an ABX Pentra 400, Horiba ABX SAS, Montpellier, France \\
${ }^{\mathrm{c}}$ Catalog number: TP 802, Tridelta Development Limited, Maynooth, Co. Kildare, Ireland \\
${ }^{\mathrm{d}}$ Catalog number: 2210-8, Life Diagnostics, Inc., West Chester, Pennsylvania, USA
\end{tabular}


Table 2 Hematologic reference intervals (RI) for buffalo calves from 10 to 30 days of life, analyzed using automated hematology analyzer (pocH$100 \mathrm{iV}$ Diff, Sysmex Corporation, Kobe, Japan)

\begin{tabular}{|c|c|c|c|c|c|c|c|c|c|}
\hline \multirow[b]{2}{*}{ Analyte } & \multirow[b]{2}{*}{ Units } & \multicolumn{4}{|c|}{ Descriptive statistics } & \multicolumn{2}{|l|}{ RI within $90 \% \mathrm{CI}$} & \multicolumn{2}{|c|}{ Reference Value Advisor } \\
\hline & & Mean & SD & Median & Min-Max & Lower limit (90\% CI) & Upper limit (90\% CI) & $n$ & Method \\
\hline $\mathrm{RBC}$ & $\times 10^{6} / \mu \mathrm{L}$ & 10.3 & 1.29 & 10.2 & $7.69-12.4$ & $7.50(6.88-8.27)$ & $12.9(12.3-13.5)$ & 28 & BCTRD \\
\hline HGB & $\mathrm{g} / \mathrm{dL}$ & 15.1 & 2.00 & 15.3 & $11.3-18.9$ & $10.6(9.10-12.2)$ & $19.0(17.9-19.9)$ & 28 & BCTRD \\
\hline $\mathrm{PCV}$ & $\%$ & 43.5 & 5.10 & 44.6 & $31.7-50.8$ & $33.1(30.0-37.1)$ & $54.8(52.2-57.8)$ & 28 & RUD \\
\hline $\mathrm{MCV}$ & $\mathrm{fL}$ & 42.4 & 3.40 & 41.6 & $36.8-49.0$ & $36.2(35.1-37.3)$ & $50.6(47.5-53.2)$ & 28 & BCTRD \\
\hline $\mathrm{MCH}$ & $\mathrm{pg}$ & 14.7 & 1.20 & 14.8 & $11.8-17.5$ & $12.1(11.4-12.9)$ & $17.3(16.6-18.0)$ & 28 & BCTRD \\
\hline $\mathrm{MCHC}$ & $\mathrm{g} / \mathrm{dL}$ & 34.9 & 3.30 & 36.1 & $29.2-38.5$ & $28.1(26.0-31.0)$ & $42.9(41.3-45.0)$ & 28 & URD \\
\hline Platelets & $\times 10^{3} / \mu \mathrm{L}$ & 675 & 173 & 665 & $372-1047$ & $361(300-433)$ & $1081(946-1213)$ & 28 & BCTRD \\
\hline WBC & $\times 10^{3} / \mu \mathrm{L}$ & 12.1 & 2.78 & 12.2 & $6.30-19.1$ & $6.56(5.24-8.13)$ & $18.2(16.5-19.9)$ & 28 & BCTRD \\
\hline Lymphocytes & $\times 10^{3} / \mu \mathrm{L}$ & 7.46 & 2.10 & 7.12 & $4.62-12.4$ & $4.15(3.80-4.73)$ & $12.8(10.9-15.0)$ & 28 & BCTRD \\
\hline SN & $\times 10^{3} / \mu \mathrm{L}$ & 4.19 & 1.95 & 3.98 & $0.61-7.64$ & $0.950(0.640-1.69)$ & $10.6(8.36-13.2)$ & 28 & BCTRD \\
\hline $\mathrm{BN}$ & $\times 10^{3} / \mu \mathrm{L}$ & 0.034 & 0.059 & 0 & $0-0.160$ & $0(0-0)$ & $0.160(0.110-0.190)$ & 28 & USD \\
\hline Monocytes & $\times 10^{3} / \mu \mathrm{L}$ & 0.259 & 0.180 & 0.281 & $0-1.10$ & $0(0-0)$ & $0.754(0.513-0.999)$ & 28 & URD \\
\hline Eosinophils & $\times 10^{3} / \mu \mathrm{L}$ & 0.064 & 0.125 & 0 & $0-0.504$ & $0(0-0)$ & $0.326(0.168-0.463)$ & 28 & USD \\
\hline Basophils & $\times 10^{3} / \mu \mathrm{L}$ & 0.030 & 0.057 & 0 & $0-0.174$ & $0(0-0)$ & $0.149(0.096-0.194)$ & 28 & USD \\
\hline
\end{tabular}

$n$ number of animals, Min minimum, Max maximum, $C I$ confidence interval, $S N$ segmented neutrophils, $B N$ band neutrophils, URD untransformed robust data, BCTRD Box-Cox transformed robust data, USD untransformed standard data

occurs probably due to a decrease in bone marrow hematopoietic activity and production of thyroid hormones with advancing age (Ciaramella et al. 2005). In the same way, when comparing results for PCV, RBC and HGB of adult animals (Fagliari et al. 1998a; Ciaramella et al. 2005; Gomes et al. 2010; França et al. 2011a; Ellah et al. 2013a, b, c; Ellah et al. 2014) with the results obtained in this work (Table 2), it was observed that concentrations are higher in our study. Also, it was observed that PCV, RBC, and HGB concentrations are higher in our study (0-30 days old) when comparing with results of 0 3-month-old buffaloes (Gomes et al. 2010) and 0-6month-old buffaloes (França et al. 2011a). This is likely to be because the age range used in these studies is older and wider than in the present study and therefore modifications in erythrogram can occur. This reinforces the importance of analyzing reference intervals specifically using calves with age ranging from 0 to 30 days of life for comparisons leading to health assessment in such young buffaloes.

WBC of buffalo calves is higher in 0-6-month-old animals when comparing with 12-month-old animals. However, after the first year, WBC increase again and stabilize in value similar to the values detected in 0-6-month-old animals (França et al. 2011a). When comparing results for WBC of adult buffaloes (Fagliari et al. 1998a; Ellah et al. 2013a, b) with the results obtained in this work (Table 2), it was observed that concentrations are higher in buffalo calves. However, when compared with studies in adult buffaloes performed by Ellah et al. (2014) and França et al. (2011a), it was observed that concentrations were similar between buffalo calves and adult buffaloes.

França et al. (2011a) compared the leukogram values between 6- and 12-month-old buffaloes and observed a decrease

Table 3 Blood serum acute phase protein (APP) reference intervals (RI) for buffalo calves from 10 to 30 days of life

\begin{tabular}{|c|c|c|c|c|c|c|c|c|c|}
\hline \multirow[b]{2}{*}{ Analyte } & \multirow[b]{2}{*}{ Units } & \multicolumn{4}{|c|}{ Descriptive statistics } & \multicolumn{2}{|l|}{ RI within $90 \%$ CI } & \multicolumn{2}{|c|}{ Reference Value Advisor } \\
\hline & & Mean & SD & Median & Min-Max & Lower limit $(90 \% \mathrm{CI})$ & Upper limit $(90 \% \mathrm{CI})$ & $n$ & Method \\
\hline Fibrinogen & $\mathrm{g} / \mathrm{L}$ & 6.07 & 1.68 & 6.00 & $2.00-10.0$ & $2.49(1.59-3.58)$ & $9.50(8.55-10.5)$ & 28 & BCTSD \\
\hline Haptoglobin & $\mathrm{g} / \mathrm{L}$ & 0.17 & 0.11 & 0.20 & $0.05-0.41$ & $0.02(0.02-0.04)$ & $0.56(0.42-0.67)$ & 20 & BCTSD \\
\hline SAA & $\mu \mathrm{g} / \mathrm{mL}$ & 49.9 & 21.9 & 45.9 & $23.3-85.8$ & $3.70(0.0-18.3)$ & $97.51(82.3-113)$ & 20 & BCTSD \\
\hline CRP & $\mu \mathrm{g} / \mathrm{mL}$ & 0.84 & 0.62 & 0.82 & $0-2.59$ & $0.02(0-0.10)$ & $2.78(1.93-3.67)$ & 20 & BCTSD \\
\hline
\end{tabular}

$n$ number of animals, SAA serum amyloid A, CRP C-reactive protein, BCSTD Box-Cox standard transformed data, BCTSD Box-Cox transformed standard data; 
in neutrophil count and increase in lymphocyte count with advancing age. However, after the first year, lymphocyte count decreased and neutrophil count increased and stabilized in values similar to or below to the values detected in 6month-old buffaloes. In this sense, when comparing results for neutrophil and lymphocyte count of adult buffaloes with the results obtained in this work (Table 2), it is observed that concentrations in or study are slightly higher or similar to other studies (Fagliari et al. 1998a; França et al. 2011a; Ellah et al. 2013a, b; Ellah et al. 2014).

Costa et al. (2000) and França et al. (2011a) in studies assessing the effect of age in the hemogram of bovine and buffalo calves, respectively, observed an increase in eosinophil count with advancing age. They concluded that this increase, especially in buffalo calves, can be due to immune response to parasites (Jain 1993), common in this age (Naag et al. 2015; Silva et al. 2015). When comparing results of eosinophil count of adult buffaloes (Fagliari et al. 1998a; França et al. 2011a; Ellah et al. 2013a, b; Ellah et al. 2014) with the results obtained in this work (Table 2), it was observed that concentrations are much lower in the present study, to about 6 to 10 times fold, which reinforces the conclusion that age causes important effects in this cell type.

Costa et al. (2000) and França et al. (2011a) observed a decrease in monocyte count with advancing age, while Jain (1993) observed no significant change with advancing age. Although some studies show a decrease in monocyte count within advancing age (França et al. 2011a), results for adult buffaloes (Fagliari et al. 1998a; Ellah et al. 2013a, b; Ellah et al. 2014) were similar or slightly higher than the concentrations analyzed in our study (Table 2).

APP are blood proteins primarily synthesized by hepatocytes as part of the acute phase response (APR). The APR is part of the innate immune system, which is triggered by different stimuli including trauma, infection, stress, neoplasia, and inflammation (Cray et al. 2009). Investigations over the last few years have shown that the quantification of APP in serum can provide valuable diagnostic information in the detection, prognosis, and monitoring of disease (Eckersall 2000). In ruminants, haptoglobin and SAA are considered major APP (10-100-fold increase in response to stimuli), while $\mathrm{CRP}$ and fibrinogen are moderate APP (2-10-fold increase in response to stimuli) (Murata et al. 2004; Eckersall and Bell 2010) and albumin a negative APP (Ceciliani et al. 2012).

Haptoglobin is a major APP in ruminants. In healthy adult cattle, the serum haptoglobin concentrations are lower than the detection limit or between 0.02 and $0.35 \mathrm{~g} / \mathrm{L}$, depending on the study (Salonen et al. 1996; Horadagoda et al. 1999; Eckersall et al. 2001; Gronlund et al. 2003; Huzzey et al. 2009; Eckersall and Bell 2010), but can increase to more than $2.0 \mathrm{~g} / \mathrm{L}$ within 2 days of infection (Eckersall and Bell 2010). Haptoglobin has already been shown to be effective in the diagnosis and prognosis of mastitis, enteritis, peritonitis, pneumonia, endocarditis, and endometritis (Murata et al. 2004; Petersen et al. 2004). In this study, the RI for haptoglobin in serum of healthy buffalo calves ranged between 0.02 and $0.56 \mathrm{~g} / \mathrm{L}$, with average of $0.17 \mathrm{~g} / \mathrm{L}$ (Table 3 ). These results are higher than measured in 3-11-month-old healthy buffaloes (average of $0.008 \mathrm{~g} / \mathrm{L}$ ) (Kabu and Sayin 2016) and adult buffaloes (average of $0.11 \mathrm{~g} / \mathrm{L}$ ) (El-Ashker et al. 2013) but lower than the observed in newborn bovine calves, with average of $0.23 \mathrm{~g} / \mathrm{L}$ (Nikunen et al. 2007) and $0.27 \mathrm{~g} / \mathrm{L}$ (Tóthová et al. 2015). Also, studies in healthy adult cattle showed that haptoglobin blood serum concentrationcan range between 0.02 and $0.10 \mathrm{~g} / \mathrm{L}$ (Eckersall et al. 2001) and that concentrations below $0.35 \mathrm{~g} / \mathrm{L}$ (Horadagoda et al. 1999) indicates that animals are healthy, different from the buffalo calves from this study (Table 3), where upper limit for haptoglobin were higher $(0.56 \mathrm{~g} / \mathrm{L})$.

SAA is also a major APP in ruminants. In healthy adult cattle (Horadagoda et al. 1999; Eckersall et al. 2001; Gronlund et al. 2003) and adult buffaloes (El-Ashker et al. 2013; Kumar et al. 2014), SAA concentrations have similar ranges. However, when comparing SAA concentrations of adult cattle and adult buffaloes with newborn bovines (Tóthová et al. 2015) and newborn buffaloes from this study (Table 3), SAA concentrations of newborn animals are at least fourfold higher than the adult animals. Additionally, SAA upper limits are similar in newborn bovines (Orro et al. 2008, 2011) and newborn buffaloes described here (Table 3).

Orro et al. (2008), in a study with newborn bovines, observed a decrease of $75 \%$ in SAA concentrations between 3 and 59 days of life. Yamanaka et al. (2003) shown that serum concentrations of pro-inflammatory cytokines of calves increase immediately after colostrum intake and then decrease gradually, being almost undetectable 3 to 4 weeks of life. Since pro-inflammatory cytokines are the main inducers of hepatic production of APP, this could explain the gradual decrease and therefore differences between newborn and adult animals, highlighting the importance of considering the age of the animal when using this protein as a disease biomarker.

CRP, a moderate APP in bovines, has been poorly studied in buffaloes. In the present work, the RI of CRP in healthy buffalo calves ranged from 0.02 to $2.78 \mu \mathrm{g} / \mathrm{mL}$ (Table 3), with average concentrations of $0.84 \mu \mathrm{g} / \mathrm{mL}$. Studies with adult buffaloes (El-Ashker et al. 2013) have found higher concentrations of serum CRP when compared with our study, with average of $25.0 \mu \mathrm{g} / \mathrm{mL}$.

Fibrinogen is an APP in ruminants used as a reliable tool for the evaluation of the response of organism to inflammation, bacterial infections, and surgical trauma (Khan et al. 1997; Murata et al. 2004). In buffaloes, França et al. (2011b) comparing 6-, 12-, and 24-month-old animals observed that serum concentrations of fibrinogen increase with age. When comparing our work (Table 3) with 0-45-day-old buffaloes (Fagliari et al. 1998b), the first month of life buffaloes (Clemente et al. 2016), and 0-5-month-old bovine calves 
(Nikunen et al. 2007), results were similar. Although França et al. (2011a) observed an increase in fibrinogen concentrations with age, when comparing to adult buffaloes, our results (Table 3) were similar to those of Fagliari et al. (1998a) but higher than the results of El-Ashker et al. (2013).

In conclusion, hematologic and acute phase protein RI for buffalo calves documented in this study can be used as a physiologic database and help the interpretation of laboratory results of newborn buffaloes during infection, inflammation, and trauma conditions. Also, when comparing results of this work with studies from the literature performed with adult animals, it is clear that the use of blood serum content of adult animals for determining the health of calves is not accurate, since many alterations occur with advancing age, highlighting the importance of undertaking further research related to hematology in newborn buffalo calves.

Acknowledgments The authors thank São Paulo Research Foundation (FAPESP) (process number: \#2008/50388-7, \#2009/12350-0, and \#2013/ 26498-5) and the University of Glasgow for the financial support.

\section{Compliance with ethical standards}

Conflict of interest The authors declare that they have no conflict of interest.

Ethical standards This research was approved by the Ethics Committee on Animal Use of Faculdade de Ciências Agrárias e Veterinárias, FCAV/UNESP (protocol number: 010885-08).

\section{References}

Ali A, Derar R, Hussein HA, Ellah MRA, Abdel-Razek AK (2011) Clinical, hematological, and biochemical findings of uterine torsion in buffaloes (Bubalus bubalis). Anim Reprod Sci 126:168-172

Anwarullah M, Khan JA, Khan MS, Ashraf K, Avais M (2014) Prevalence of Salmonella and Escherichia coli associated with diarrhea in buffalo and cow calves. Buffalo Bulletin 33:332-336

Benesi FJ, Teixeira CMC, Lisboa JAN, Leal MLR, Júnior EHB, Bohland E, Mirandola RMS (2012a) Erytrogram of healthy female Holstein calves during the first month of life. Brazilian Journal of Veterinary Research 32:357-360

Benesi FJ, Teixeira CMC, Leal MLR, Lisbôa JAN, Mirandola RMS, Shecaira CL, Gomes V (2012b) Leukograms of healthy Holstein calves within the first month of life. Brazilian Journal of Veterinary Research 32:352-356

Brun-Hansen HC, Kampen AH, Lund A (2006) Hematologic values in calves during the first 6 months of life. Vet Clin Pathol 35:182-187

Ceciliani F, Ceron JJ, Eckersall PD, Sauerwein H (2012) Acute phase proteins in ruminants. J Proteome 75:4207-4231

Ciaramella P, Corona M, Ambrosio R, Consalvo F, Persechino A (2005) Haematological profile on non-lactating Mediterranean buffaloes (Bubalus bubalis) ranging in age from 24 months to 14 years. Res Vet Sci 79:77-80

Clemente V, Santana AM, Silva DG, Silveira CRA, Pizauro LJL, Clemente Z, Fagliari JJ (2016) Acute phase response in buffalo calves experimentally infected with Salmonella typhimurium. Pak Vet J 36:153-158
Costa JN, Benesi FJ, Birgel EH, D'Angelino JL, Ayres MCC, Filho IRB (2000) Influence of age on the leukogram values for healthy Nelore (Zebu) cattle. Ciência Rural 30:399-403

Cray C, Zaias J, Altman NH (2009) Acute phase response in animals: a review. Comparative Medicine 59:517-526

Eckersall PD (2000) Recent advances and future prospects for the use of acute phase proteins as markers of disease in animals. Rev Med Vet 151:577-584

Eckersall PD, Bell R (2010) Acute phase proteins: biomarkers of infection and inflammation in veterinary medicine. Vet J 185:23-27

Eckersall PD, Duthie S, Safi S, Moffatt D, Horadagoda NU, Doyle S, Parton R, Bennett D, Fitzpatrick JL (1999) An automated biochemical assay for haptoglobin: prevention of interference from albumin. Comp Haematol Int 9:117-124

Eckersall PD, Young FJ, Mccomb C, Hogarth CJ, Safi S, Weber A, Mcdonald T, Nolan AM, Fitzpatrick JL (2001) Acute phase proteins in serum and milk from dairy cows with clinical mastitis. Vet Rec 148:35-41

E1-Ashker M, Salama M, E1-Boshy M (2013) Traumatic reticuloperitonitis in water buffalo (Bubalus bubalis): clinical findings and the associated inflammatory response. J Vet Med. doi:10. $1155 / 2013 / 808656$

Ellah MRA, Hamed MI, Derar RI (2013a) Serum biochemical and hematological reference values for lactating buffaloes. Comp Clin Pathol. doi:10.1007/s00580-013-1760-2

Ellah MRA, Hamed MI, Derar RI, Rateb HZ (2013b) Comparative study on reference values for blood constituents during pregnancy in buffaloes (Bubalus bubalis). Journal of Advanced Veterinary and Animal Research 3:36-46

Ellah MRA, Hamed MI, Derar RI (2013c) Serum biochemical and haematological reference values for midterm pregnant buffaloes. J Appl Anim Res 41:309-317

Ellah MRA, Hamed MI, Ibrahim DR, Rateb HZ (2014) Serum biochemical and haematological reference intervals for water buffalo (Bubalus bubalis) heifers. J S Afr Vet Assoc. doi:10.4102/jsava. v85i1.962

Fagliari JJ, Santana AE, Marchio W, Campos Filho E, Curi PR (1998a) Blood constituents of Nelore cattle (Bos indicus), Holstein cattle (Bos taurus) and Murrah buffalo (Bubalus bubalis) cows during pregnancy, at the time of calving and at post-partum. Brazilian Journal of Veterinary and Animal Sciences 50:273-282

Fagliari JJ, Santana AE, Lucas FA, Campos FE, Curi PR (1998b) Blood constituents of the newborn Nelore cattle (Bos indicus), Holstein cattle (Bos taurus) and Murrah buffalo (Bubalus bubalis). Brazilian Journal of Veterinary and Animal Sciences 50:253-262

França RT, Lopes STA, Martins DB, Costa MM, Leal MLR, Mazzanti CMA, Schuh R, Dornelles GL (2011a) Hematological parameters of buffaloes of different ages reared in the central region of Rio Grande do Sul. Revista Brasileira de Ciência Veterinária 18:51-54

França RT, Costa MM, Martins DB, Pagnoncelli M, Leal ML, Mazzanti CM, Palma HE, Kunert CP, Paim FC, Lopes STA (2011b) Protein profile of buffaloes of different ages. Acta Sci Vet 39:995

Friedrichs KR, Harr KE, Freeman KP, Szladovits B, Walton RM, Barnhart KF, Blanco-Chavez J (2012) ASVCP reference interval guidelines: determination of de novo reference intervals in veterinary species and other related topics. Vet Clin Pathol 41:441-453

Garcia-Navarro CEK (1994) Manual de hematologia veterinária. Varela, São Paulo 169 p

Geffré A, Concordet D, Braun JP, Trumel C (2011) Reference Value Advisor: a new freeware set of macroinstructions to calculate reference intervals with Microsoft Excel. Vet Clin Pathol 40:107-112

Gomes V, Moura JA, Madureira KM, Baptistella F, Kitamura SS, Blagitz MG, Benesi FJ (2010) Reference values and influence of age on erythrogram of Murrah buffaloes. Brazilian Journal of Veterinary Research 30:301-304 
Gronlund U, Hulten C, Eckersall PD, Hogarth C, Waller KP (2003) Haptoglobin and serum amyloid $\mathrm{A}$ in milk and serum during acute and chronic experimentally induced Staphylococcus aureus mastitis. J Dairy Res 70:379-386

Horadagoda NU, Knox KMG, Gibbs HA, Reid SWJ, Horadagoda A, Edwards SER, Eckersall PD (1999) Acute phase proteins in cattle: discrimination between acute and chronic inflammation. Vet Rec 144:437-441

Horadagoda NU, Hodgson JC, Moon GM, Wijewardana TG, Eckersall PD (2001) Role of endotoxin in the pathogenesis of haemorrhagic septicaemia in the buffalo. Microb Pathog 30:171-178

Horadagoda NU, Hodgson JC, Moon GM, Wijewardana TG, Eckersall PD (2002) Development of a clinical syndrome resembling haemorrhagic septicaemia in the buffalo following intravenous inoculation of Pasteurella multocida serotype B:2 endotoxin and the role of tumour necrosis factor- $\alpha$. Res Vet Sci 72:194-200

Huzzey J, Duffield T, LeBlanc S, Veira D, Weary D, von Keyserlingk M (2009) Short communication: haptoglobin as an early indicator of metritis. J Dairy Sci 92:621-625

Jain NC (1993) Schalm's veterinary hematology. 4 ed. Philadelphia : Lea and Febiger, 1986. Cattle normal hematology with comments on response to disease: p.178-207

Kabu M, Sayin Z (2016) Concentrations of serum amyloid A, haptoglobin, tumour necrosis factor and interleukin-1 and -6 in Anatolian buffaloes naturally infected with dermatophytosis. Veterinarni Medicina 61:133-135

Khan MZ, Muhammad G, Umar A, Khan SA (1997) A preliminary comparison of plasma fibrinogen concentrations, leukocyte numbers and erythrocyte sedimentation rate as non-specific indicators of inflammatory conditions in buffalo (Bubalis bubalis). Vet Res Commun 21:265-271

Khan JA, Khan MS, Khan MA, Avais M, Maqbool A, Salman M, Rehman ZU (2009) Epidemiology of major bacterial and viral causes of diarrhea in buffalo calves in three districts of the Punjab province of Pakistan. J Zool 9:187-193

Kumar P, Sharma A, Sindhu N, Deora A (2014) Acute phase proteins as indicators of inflammation in streptococcal and staphylococcal mastitis in buffaloes. Haryana Veterinarian 53:46-49

Millar HR, Simpson JG, Sralken AL (1971) An evaluation of the heat precipitation method for plasma fibrinogen estimation. J Clin Pathol 24:827-830

Murata H, Shimada N, Yoshioka M (2004) Current research on acute phase proteins in veterinary diagnosis: an overview. Vet J 168:28-40

Naag D, Swamy M, Shrivastav AB (2015) Enteric parasitic infection in diarrheic buffalo calves. Buffalo Bulletin 34:223-225

Neamat-Allah, ANF (2015) Alterations in some hematological and biochemical parameters in Egyptian buffaloes suffering from traumatic reticuloperitonitis and its sequelae. 2015. Bulletin UASVM Veterinary Medicine. doi: 10.15835/buasvmen-vm:11021

Nikunen S, Hartel H, Orro T, Neuvonen E, Tanskanen R, Kivela SL, Sankari S, Aho P, Pyorala S, Saloniemi H, Soveri T (2007) Association of bovine respiratory disease with clinical status and acute phase proteins in calves. Comparative Immunology Microbiology And Infectious Diseases 30:143-151

Orro T, Jacobsen S, LePage JP, Niewold T, Alasuutari S, Soveri T (2008) Temporal changes in serum concentrations of acute phase proteins in newborn dairy calves. Vet J 176:182-187

Orro T, Pohjanvirta T, Rikula U, Huovilainen A, Alasuutari S, Sihvonen L, Pelkonen S, Soveri T (2011) Acute phase protein changes in calves during an outbreak of respiratory disease caused by bovine respiratory syncytial virus. Comparative Immunology Microbiology And Infectious Diseases 34:23-29

Petersen HH, Nielsen JP, Heegaard PMH (2004) Application of acute phase protein measurement in veterinary clinical chemistry. Vet Res 35:163-187

Rizzoli FW, Fagliari JJ, Silva DG, Silva SL, Jorge RLN (2006) Proteinogram and serum levels of calcium, phosphorus, magnesium and iron in newborn calves suckling colostrum from the cow or nipple bottle. Ars Veterinária 22:198-202

Saleh MA, Rateb HZ, Misk NA (2008) Comparison of blood serum proteins in water buffaloes with traumatic reticuloperitonitis and sequellae. Res Vet Sci 85:208-213

Salonen M, Hirvonen J, Pyorala S, Sankari S, Sandholm M (1996) Quantitative determination of bovine serum haptoglobin in experimentally induced Escherichia coli mastitis. Res Vet Sci 60:88-91

Sample SH, Fox KM, Wunn D, Roth E, Friedrichs KR (2015) Hematologic and biochemical reference intervals for adult Friesian horses from North America. Vet Clin Pathol 44:194-199

Silva DG, Silva PRL, Fagliari JJ (2010) Blood cell counts and serum biochemical profile, including blood gas levels, in Salmonella dublin-infected calves. Brazilian Journal of Veterinary and Animal Sciences 62:251-257

Silva DG, Silva PRL, Silva PC, Fagliari JJ (2011) Serum protein concentrations, including acute phase proteins, in calves experimentally infected with Salmonella dublin. Brazilian Journal of Veterinary Research 31:551-554

Silva DG, Santana AM, Pizauro LJL, Bernardes PA, Clemente V, Silveira CRA, Christoforo MT, Fagliari JJ (2015) Toxocara vitulorum in newborn buffalo calves. Investigação 14:102-104

Singh ND, Banga HS, Gadhave PD, Mugale MN (2013) A retrospective evaluation of haematological values in clinical cases of water buffaloes. Veterinary World 6:103-105

Sunil Chandra NP, Mahalingam S (1994) Rotavirus associated diarrhoeas in buffalo calves in Sri Lanka. In: World Buffalo Congress, 4., 1994, São Paulo. Proceedings... São Paulo: 1994. Vol II: p. 322-324

Tajik J, Nazifi S, Heidari M, Babazadeh M (2012) Evaluation of serum proteins in water buffaloes (Bubalus bubalis) with abomasal ulcer. Asian Journal of Animal and Veterinary Advances 7:277-282

Tóthová C, Nagy O, Nagyová V, Kováč G (2015) Changes in the concentrations of acute phase proteins in calves during the first month of life. Acta Vet-Beogr 65:260-270

Yamanaka H, Hagiwara K, Kirisawa R, Iwai H (2003) Transient detection of pro-inflammatory cytokines in sera of colostrum-fed newborn calves. J Vet Med Sci 65:813-816 